\title{
RESISTANCE OF SEEDLING WHITE CLOVER CULTIVARS TO REDLEGGED EARTH MITE HALOTYDEUS DESTRUCTOR
}

\author{
S.L. MARSHALL, T.J. RIDSDILL-SMITH ${ }^{1}$ and R.A. PRESTIDGE \\ AgResearch, Ruakura Research Centre, Private Bag 3123, \\ Hamilton, New Zealand \\ ${ }^{1}$ CSIRO Division of Entomology, Private Bag, Wembley, WA 6014, Australia
}

\begin{abstract}
Two glasshouse pot bioassays were conducted in Perth, Western Australia, in 1994 which compared the seedling resistance of subterranean clover (Trifolium subterraneum L.) with New Zealand white clover (Trifolium repens L.) cultivars 'Grasslands Huia', 'Grasslands Tahora', 'Prop', 'Grasslands Pitau' and 'Grasslands Kopu' to redlegged earth mite (Halotydeus destructor) (Acarina: Penthaleidae). Plant wet weights, mite development and survival and plant damage scores were monitored. Subterranean clover was more resistant to redlegged earth mite than white clover in both experiments. The white clover cultivars, 'Grasslands Pitau' and 'Grasslands Kopu' had lower cotyledon damage scores and higher yields than the other white clover cultivars.
\end{abstract}

Keywords: Redlegged earth mite,Halotydeus destructor, white clover, subterranean clover, plant resistance

\section{INTRODUCTION}

Redlegged earth mite (Halotydeus destructor) (Acarina: Penthaleidae) (RLEM) is present in South Africa, Australia and New Zealand (Jeppson et al. 1975) in areas with a Mediterranean-type climate with rainfall occurring mainly during winter. It is a major pest of pastures in southern Australia feeding mainly on pasture legumes, particularly subterranean clover, white clover and medics (Medicago spp.). The cost to the Australian wool and beef industries is estimated at approximately \$56-112M and \$81M respectively, in lost wool and cattle production (Ridsdill-Smith 1991). In New Zealand, RLEM occurs in summer-dry environments in the eastern Bay of Plenty, Hawkes Bay and coastal Manawatu. Little is known of the pest status of RLEM in these areas. It is also a seedling and phytosanitary pest of vegetable crops such as asparagus (Willoughby and Watson 1996) which are exported as fresh produce to the United States.

RLEM feed on the upper surface of cotyledons and leaves where they penetrate the cell membrane with their chelicerae and suck out the cell contents. Establishing legume plants are most at risk, although feeding mites may reduce quality of established pasture and hence animal production (Ridsdill-Smith 1991).

In Australia several pasture legume screening programmes have attempted to identify RLEM resistant plants (Stahle 1987; Berg 1991; Gillespie 1991). In Western Australia, approximately $4 \%$ of the subterranean clover varieties and annual medic varieties have been identified as resistant to RLEM (Gillespie 1991). Resistance in seedlings is caused by antifeeding mechanisms through antixenosis (Jiang and RidsdillSmith 1996) Increasingly white clover cultivars developed under New Zealand conditions are being exported to Australia but little is known about their relative susceptibility to RLEM.

This paper reports on two experiments which evaluated white clover seedling resistance to RLEM. The research was undertaken as part of a five week technical exchange programme between AgResearch Ruakura and CSIRO, Perth.

\section{METHODS}

Two glasshouse experiments were conducted in Perth, Western Australia, during the Proc. 50th N.Z. Plant Protection Conf. 1997: 56-60 
winter with daily ambient temperatures ranging from 8 to $21^{\circ} \mathrm{C}$. The subterranean clover cultivars selected were either susceptible (Dalkeith) or resistant (SE020) as seedlings to RLEM (Ridsdill-Smith 1995). The white clovers selected were from the range of commercial cultivars available in New Zealand (Table 1).

In the first experiment 15 mechanically scarified clover seeds of the same cultivar were sown to a depth of $10 \mathrm{~mm}$ into $120 \mathrm{~mm}$ diameter pots containing a pre-watered 4 : 1 sand: loam mix. Treatments comprised of 7 cultivars with 10 replicate pots (Table 1 ). Each seed was covered with a rhizobium inoculum: soil mix (5 g inoculum to $100 \mathrm{~g}$ soil). Vented clear plastic covers were placed over the pots to restrict the RLEM to the pots (Ridsdill-Smith 1995). Seeds germinated after eight days in a constant temperature room at $15^{\circ} \mathrm{C}$. The pots were then transferred to a glasshouse and arranged into randomised blocks. Plants were thinned to 12 seedlings per pot. Sixty field-collected RLEM at the deutonymph stage were released onto each pot and contained by the plastic cover.

On Day 17 after sowing, damage to clover seedlings was scored using a subjective rating $(1=$ no damage to $10=$ total destruction $)$. Live mites were counted and sorted into life stages and the above ground herbage was harvested and weighed.

The second experiment was the same as the first except that equal seed weights were used in preference to equal seed numbers due to the size difference between subterrenean clover and white clover seed and the subsequent surface area of cotyledons of the seedlings. The mechanically scarified white clover seeds were scattered evenly over the soil surface then covered with inoculum: soil mix and misted lightly with water. The subterranean clovers were sown as for the first experiment. RLEM at the tritonymph stage were used.

The untransformed data were subjected to statistical analysis using ANOVA.

\section{RESULTS}

In experiment one the wet weight of the subterranean clover seedlings was greater than those of white clover $(\mathrm{P} \leq 0.001$; Fig. 1$)$. Germination was reasonably even between treatments. The white clover cultivars 'Grasslands Kopu' and 'Grasslands Pitau' had higher wet weights than the other white clover cultivars $(\mathrm{P} \leq 0.001 ;$ Fig. 1$)$. There were no significant differences in total mite numbers between the treatments over all active stages after 17 days (Table 1). There was significantly more damage to the white clover cultivars than the subterranean clovers on Day 17 (P $\leq 0.001$; Fig. 2a). Of the white clovers, 'Grasslands Kopu' and 'Grasslands Pitau' had significantly lower damage scores than 'Grasslands Huia', 'Grasslands Tahora' and 'Prop'(P $\leq 0.01$; Fig. 2a). Subterranean clover SE020 had significantly less RLEM damage than Dalkeith $(\mathrm{P} \leq 0.001$; Fig. 2a).

TABLE 1: Total mites (Experiment 1 and 2), egg densities (Experiment 2) and percentage germination of clovers (Experiment 2).

\begin{tabular}{|c|c|c|c|c|c|c|c|c|}
\hline & \multicolumn{2}{|c|}{ Subterranean clover } & \multicolumn{5}{|c|}{ White Clover } & \multirow[b]{2}{*}{ SED } \\
\hline & Dalkeith & DGI007 & Huia & Tahora & Prop & Pitau & Kopu & \\
\hline \\
\hline (Exp. 1) & 17.6 & 14.6 & $\overline{15.2}$ & 17.7 & 16.3 & 20.4 & 21.5 & 4.31 \\
\hline Total mites & & & & & & & & \\
\hline (Exp. 2) & 16.6 & 18.1 & 16.7 & 20.1 & 15.4 & 13.7 & 18.8 & 3.88 \\
\hline $\begin{array}{l}\text { Total eggs } \\
\text { (Exp. 2) }\end{array}$ & 1.6 & 0.2 & 1.5 & 12.7 & 6.0 & 9.5 & 11.8 & 2.86 \\
\hline $\begin{array}{l}\text { \%Germination } \\
\text { (Exp. 2) }\end{array}$ & 98.0 & 100.0 & 23.0 & 44.0 & 23.0 & 71.0 & 82.0 & 4.6 \\
\hline
\end{tabular}

In experiment two, germination visual score was higher for the subterranean clovers than white clovers (P $\leq 0.001$; Table 1). 'Grasslands Pitau' and 'Grasslands Kopu' had higher germination visual scores than the other white clover cultivars $(\mathrm{P} \leq 0.001$; Table 


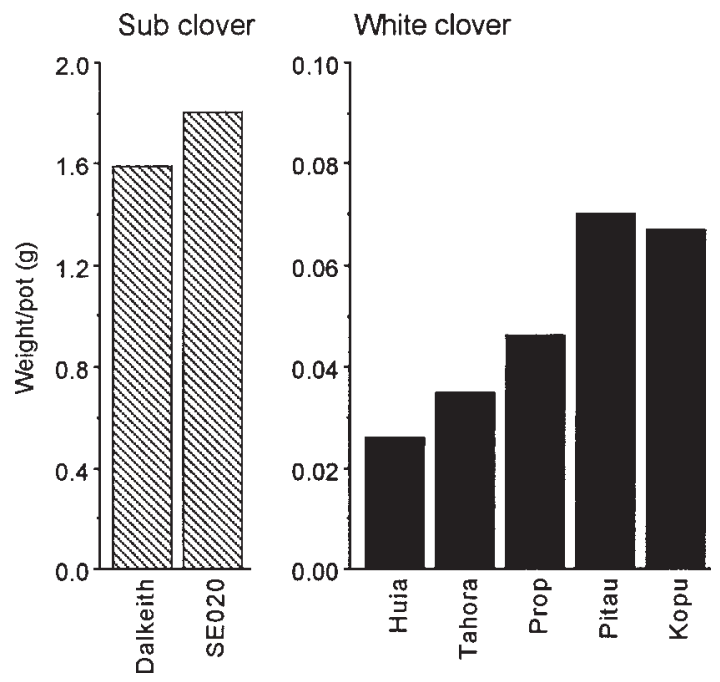

FIGURE 1: Wet weight (g) of white clover and subterranean clover cultivars 17 days after sowing for Experiment $1 . \operatorname{LSD}(5 \%)=0.32$ and 0.03 for subterranean and white clover respectively.

a)

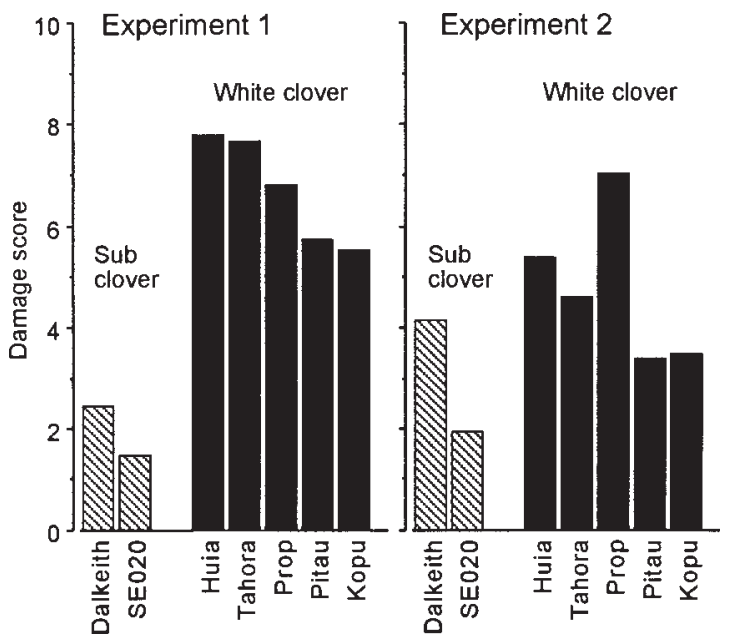

FIGURE 2: Redlegged earth mite damage scores for both experiments on white clover and subterranean clover cultivars on Day 17. $\operatorname{LSD}(5 \%)=1.8$ and 1.8 for Experiments 1 and 2 respectively.
a) Experiment 1
b) Experiment 2 
1). The wet weights of the subterranean clovers were significantly higher than those of white clovers ( $\mathrm{P} \leq 0.001$; Fig. 3). Among the white clover cultivars, 'Grasslands Kopu' and 'Grasslands Pitau' had significantly higher wet weights than the other cultivars (P $\leq 0.001$; Fig. 3).

Compared with the subterranean clovers, RLEM egg numbers were significantly higher on white clover cultivars with the exception of 'Grasslands Huia' and 'Prop' $(\mathrm{P} \leq 0.001$; Table 1). Subterranean clover damage scores were higher on Dalkeith than SE020 (P $\leq 0.001$; Fig. 2b). Among the white clovers 'Grasslands Pitau' and 'Grasslands Kopu' again had lower damage scores than the other white clover cultivars $(\mathrm{P} \leq 0.001$; Fig. 2b).

\section{DISCUSSION}

Resistance to RLEM feeding can be defined in terms of feeding damage (Gillespie 1991; Ridsdill-Smith 1995). Subterranean clovers were more resistant than white clover

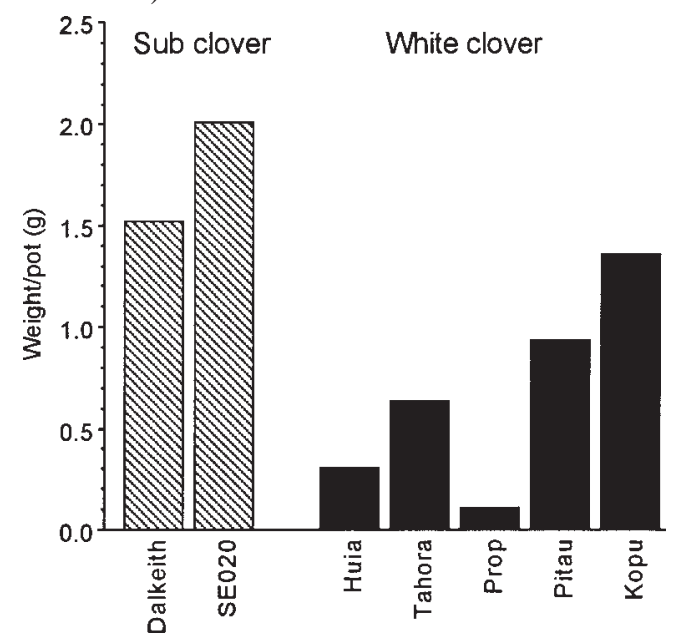

\section{FIGURE 3: Plant wet weight (g) for all cultivars 17 days after sowing for Experiment 2. $\operatorname{LSD}(5 \%)=0.26$.}

in terms of lower damage scores and greater plant wet weight. Average feeding damage by RLEM to cotyledons of subterranean clover was $28 \%$ of that of white clover for experiment one. Experiment two showed damage to subterranean clover cotyledons to be $64 \%$ of that of white clover. Average feeding damage by RLEM to cotyledons of the white clovers 'Grasslands Kopu' and 'Grasslands Pitau' in experiment one was 76\% that of 'Grasslands Huia', 'Grasslands Tahora' and 'Prop'. In experiment 2 the average damage score for 'Grasslands Kopu' and 'Grasslands Pitau' was 60\% that of 'Grasslands Huia', 'Grasslands Tahora' and 'Prop'. Although a low level of resistance was demonstrated among the white clovers, it was considerably less than subterranean clover. The resistance observed in subterranean clover SE020 confirms the results of Ridsdill-Smith (1995). The white clover cultivars have not been tested before with RLEM.

Other studies have used mite reproduction and development as measures of plant resistance when feeding on crop plants (e.g. Ridsdill-Smith 1995; Wilde et al. 1991; Mansour and Karchi 1990; Byrne et al. 1982). In the current experiments, the lowest numbers of eggs were recorded on the subterranean clover cultivars and 'Grasslands Huia' white clover. In experiments conducted over a longer period it would be interesting 
to determine whether low mite egg density on 'Grasslands Huia' would have continued into low population development.

The ranking of damage was similar in both experiments with equal numbers of seedlings and equal weight of seeds ('Grasslands Huia', 'Grasslands Tahora', 'Prop' > 'Grasslands Kopu', 'Grasslands Pitau' > Dalkeith, SE020). The germination rates were ranked the same as the damage scores. It is suggested that the lines which were most susceptible were smaller seeded, producing smaller seedlings, and that individual small plants were more susceptible to mite damage.

It is unlikely that the low level of resistance to RLEM exhibited by these white clover cultivars would be adequate to avoid severe damage to white clover plants in the field in areas of high levels of RLEM infestation. Resistance to RLEM (and significant insect pests) could be included as an objective of cultivar improvement programmes conducted by plant breeders and geneticists.

\section{ACKNOWLEDGEMENTS}

The authors wish to thank the following people. Tanya Picen for assistance and guidance with the experiments. The staff at Entomology Division of CSIRO at Floreat Park, Perth, for their support during my visit. Catherine Cameron for statistical analysis.

\section{REFERENCES}

Berg, G., 1991. Redlegged earth mite, blue oat mite, lucerne flea and associated arthropods - an historical perspective.Australian Proc. Nat. Workshop Redlegged Earth Mite, Perth: 10-13.

Byrne, D.H., Guerrero, J.M., Belloti, A.C. and Gracen, V.E., 1982. Behaviour and development of Mononychellus tanajoa (Acari: Tetranychidae) on resistance and susceptible cultivars of cassava. J. Econ. Ent. 75: 924-7.

Gillespie D.V., 1991. Identification of resistance to redlegged earth mite (Halotydeus destructor) in pasture legumes. Plant Prot. Quart. 6: 168-169.

Jeppson, L.R., Keifer, H.H. and Baker, E.W, 1975. Mites injurious to economic plants: 614.In: Eriophyid Studies. University of California Press, Berkley, California.

Jiang, Y. and Ridsdill-Smith, T.J., 1996. Antixenotic resistance of subterranean clover cotyledons to redlegged earth mite, Halotydeus destructor. Ent. Exp. et Appl. 79: 161-69.

Mansour, F. and Karchi, Z., 1990. The evaluation of antibiosis of selected lines for resistance of melon to the carmine spider mite Tetranychus cinnabarinus (Acari: Tetranychidae). Bull. Ent. Res. 80: 345-7.

Ridsdill-Smith, T.J., 1991. A contribution to assessing the economic impact of redlegged earth mite on agricultural production in Australia. Plant Prot. Quart. 6: 168-169.

Ridsdill-Smith, T.J., 1995. Responses and feeding damage of redlegged earth mite (Acarina: Penthaleidae) to seedlings of resistant and susceptible subterranean clover cultivars. Aust. J. Agric. Res. 46: 1091-9.

Stahle, P.P., 1987. Resistance of four white clover cultivars to attack by redlegged earth mite. Pp 232-234In: Temperate Pastures: their Production, Use and Management. J.L. Wheeler, C.J. Pearson and G.E. Robards (Eds); Aust. Wool Corp, CSIRO, Australia.

Wilde, G., Thomas, W. and Hall. H., 1991. Plant resistance to twospotted spider mite (Acari: Tetranychidae) in raspberry cultivars. J. Econ. Ent. 84: 251-5.

Willoughby, B. and Watson, R.N., 1996. Pest problems in asparagus. In: The New Zealand Asparagus Manual, 2nd Edition. L. McKewan (Ed) (in press). 